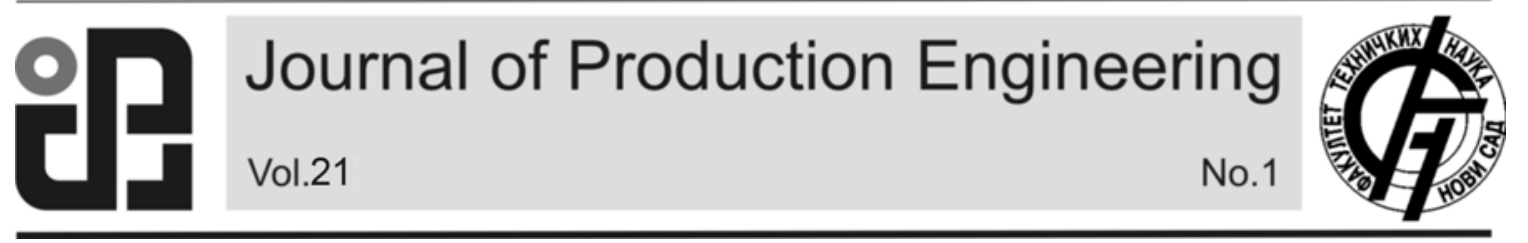

JPE (2018) Vol.21 (1)

Kovač, P., Savković, B., Rodić, D., Gostimirovic M., Mankova, I.

Original Scientific Paper

\title{
WEAR OF MODEL AND INTEGRAL FACE MILLING CUTTER MODELLED BY ARTIFICIAL INTELLIGENCE
}

Received: 27 January 2018 / Accepted: 25 May 2018

\begin{abstract}
The paper presents results of experimental study of model single tooth and integral multi tooth milling cutter. During the study research were tool wear on rake face and flank face of face milling cutter during processing time. Radial and axial throw of tooth were small and wear parameters are during processing time remain near for both cases. Tool wear of model single tooth and eight teeth face milling cutter were modeled by statistical method and artificial intelligence neural network model and were compared. Better models were achieved with artificial intelligence method.
\end{abstract}

Key words: Wear parameters, face milling, modelling, neural network.

Modelovanje habanja alata modelskog i integralnog čeonog glodala primenom veštačke inteligencije. Rad prikazuje rezultate eksperimentalnih ispitivanja modelske glave za glodanje sa jednim zubom i integralne glave za glodanje sa osam zuba. Tokom procesa ispitivanja mereno je habanje zuba na grudnoj i leđnoj površini tokom vremena obrade. Pošto je radijalno $i$ aksijalno bacanje zuba glave za glodanje bilo malo, $i$ habanje za oba ispitivana slučaja slučaja bilo vrlo slično. Zatim je habanje modelskog jednozubog i glodala sa osam zuba modelirano statističkim metodama i pomoću veštačke neuronske mrě̌e. Bolje slaganje merenih i računskih vrednosti je postignuto pomoću metoda veštačke inteligencije.

Ključne reči: Parametri habanja, čeono glodanje, modeliranje, neuronske mreže.

\section{INTRODUCTION}

Face milling is very efficient machining process, because the metal removal rate is higher in comparison with single point tool. Because of higher amount of material waste, most of tool life tests are in face milling are done with a single tool and the results are used for multi-tooth tool life prediction. The total tool life of multi-tooth cutter is multiplying the values of single tooth cutter by number of teeth is obtained. The phenomenon of tool life reduction in case of multi-toot cutter in comparison with single toot cutter during machining with constant cutting regime was observed in the paper.

There are usually two types of run-out recognized, it is radial and axial throw. Both types of throw yield influence on the cutting parameters [1]. The axial throw directly influences of surface roughness parameters. Both types of throw causes variation in chip cross section it is high cutting forces. The heavier chip cross section results in increasing cutting temperature and cutting force on discussed insert.

The paper [2] describes the implementation of a cutting force prediction model for milling that introduces radial engagement reduction caused by tool runout and workpiece flexibility, although tool wear is not considered.

Modeling of the output responses: surface roughness, cutting force, cutting power, specific cutting force and metal removal rate during the face milling with software ANOVA was used for evaluating the influence of the cutting regime parameters, namely: cutting speed, feed per tooth and depth of cut on the output machining process responses in [3] .

Besides well-established AI techniques, ensemble methods in [4] simultaneously use several AI models, where all the predictions are combined. The high accuracy of ensemble predictions has been demonstrated in many milling processes.

Paper [5] proposes a method for cutting parameters identification using the multi-inputs-multi-outputs fuzzy inference system. The fuzzy inference system was used to identify the initial values for cutting parameters (cutting speed, feed rate and depth of cut) and flank wear using cutting temperature and tool life as outputs.

Whenever the tool wear reaches a point where the design surface roughness cannot be attained or the tool wear approaches maximum values, forced cutting tool replacement is necessary. In this case, the direct method of controlling tool wear is used. When the tool wear approaches maximum values, forced cutting tool replacement is necessary. In this case, the direct method of controlling tool wear is used [6].

A combination of signal processing techniques to obtain improved and robust estimates of tool wear used [7]. In paper [8] demonstrated was the use of a probabilistic neural network in monitoring tool wear in the end-milling operation via acoustic emission and cutting power signals.

The use of artificial intelligence methods is suggested in paper [9] for real-time prediction of surface roughness deviations, depending on the main drive power, and tool wear parameter, VB into account.

A series of artificial intelligence methods are tested: random forest, standard Multi-layer perceptron's, 
Regression Trees, and radial-based functions. Random forest was shown to have the highest model accuracy, followed by regression trees, displaying higher accuracy than the standard MLP and the radial-basis function [9].

The wear outputs from the ANN model are then tested in [9]. It was observed that as the model using ANN provided quite satisfactory results, and that it can be used for online tool wear estimation.

The aim of this study was to prove that the tool wear on the same tooth, when machining is done with single tooth or multi-tooth cutter has approximately same values. The experimental results were modeled by ANN and compared to measured.

\section{MATERIAL AND METHOD}

The investigation was done with constant cutting regime. At first with single tooth cutter, then with multi-tooth cutter and parameters of tool wear on rake and flank face were measured. To avoid influence on the results radial and axial throw of during study kept constant in limit $\pm 0.002 \mathrm{~mm}$.

The experiment has been carried out on correction



The eight-teeth face milling cuter with hard metal inserts SPAN 1203 ER, P25 quality were used as processing tool. The geometrical elements of face milling tool cutting part did not vary and were: tool normal rake $7^{\circ}$ tool normal crealance $18^{\circ}$ and tool cutting edge angle $75^{\circ}$.

The experiments have been carried out on vertical milling machine, with driving power of $14 \mathrm{~kW}$. Cutting regime were: cutting speed $\mathrm{v}(\mathrm{m} / \mathrm{s})$, feed $\mathrm{f}(\mathrm{mm} /$ teeth) and depth of cut (axial) a (mm). All machining tests were carried out without application cooling and lubrication agent. Cutting speed $\mathrm{v}=2.95 \mathrm{~m} / \mathrm{s}$ depth of cut $\mathrm{a}=1.5 \mathrm{~mm}$, two values of feed per tooth $\mathrm{f}=0.223$ and $0.142 \mathrm{~mm} /$ tooth.

The measurement of wear on face surface and flank one of milling tool performed periodically on universal tool microscope Fig. 1. Photos of wear on rake and flank tool surface for different feeds per tooth was done on Scanning electron microscope.

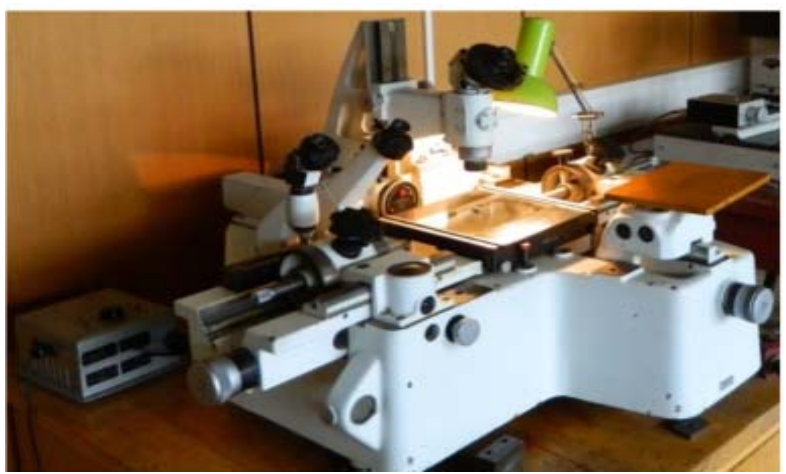

Fig. 1. Universal tool microscope

\section{NEURAL NETWORK}

The basic architecture of a Neural Network typically consists of an input function, which can take the form of binary, continuous or normalized data: a processing architecture which consist of transfer function description, summation function, and relative learning strategy: a method for identifying and learning from past errors in estimates: and finally a mechanism for feeding error corrections back into the network [10]. A multilayer feed-forward network has been used, and the backpropagation training algorithm has been employed to train the network. Backpropagation is a systematic method for training multilayer ANN. A backpropagation network is a multilayer feed-forward network which uses gradient-descent method to minimize the total squared error of the output computed by the net. The training algorithm of back-propagation involves four stages which are initialization of weights, feed-forward, backpropagation of errors, and updating the weights and biases [11].

Modeling of the tool wear with feed forward neural network is composed of two stages: training and testing of the network with experimental machining data [12, 13]. The scale of the input and output data is an important matter to consider, especially when the operating ranges of process parameters are different. The scaling or normalization ensures that the ANN will be trained effectively without any particular variable skewing the results significantly. As a result, all the input parameters are equally important in the training of network.

The architecture of the designed network comprises one input neuron corresponding to one input parameter, an output layer with one neuron corresponding to one output parameter at a time, and a single hidden layer of neurons. The transfer functions which have been used are tansig and purelin in hidden and output layers, respectively. The transfer function tansig is a hyperbolic tangent sigmoid transfer function, and purelin is a linear transfer function. With the help of back propagation training data set (Input parameter related to output parameters) is set to utilize to train the neural network. One input parameter and one output parameter are considered. The selected input parameters should be easily variable and can be easily changed by the operator.

- Selected input parameter is: processing time ( $\mathrm{min})$

- Selected output parameter is: width of flank wear land (mm), figure 2 .

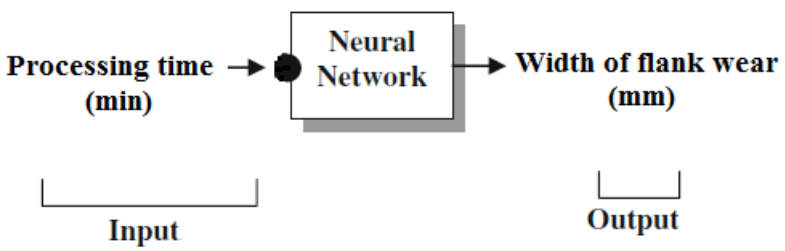

Fig. 2. Network input and output layer

It must be highlighted that the best network architecture is reached by trial and error after considering different combinations of the number of neurons in the hidden layer, the number of hidden layers, spread parameter, and learning rate, depending on the type of neural network being used. 


\section{RESULTS AND ANALYSIS}

Figure 3 and 4 shows SEM micrographs of wear on rake and flank tool surface for different feeds per tooth.
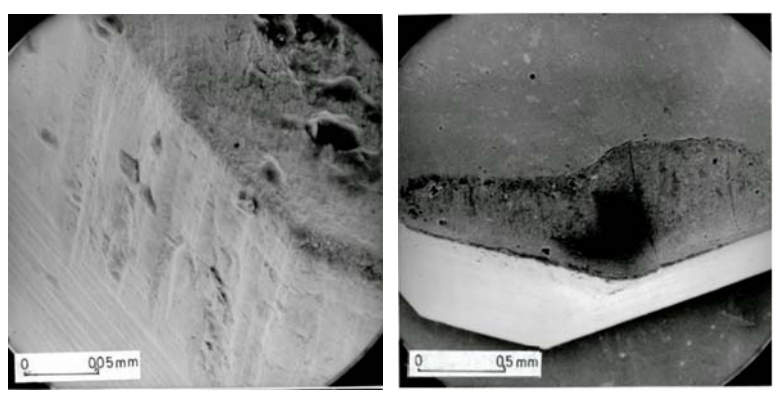

Fig. 3. SEM micrograph of tool wear for $\mathrm{f}=0.223$ $\mathrm{mm} /$ tooth
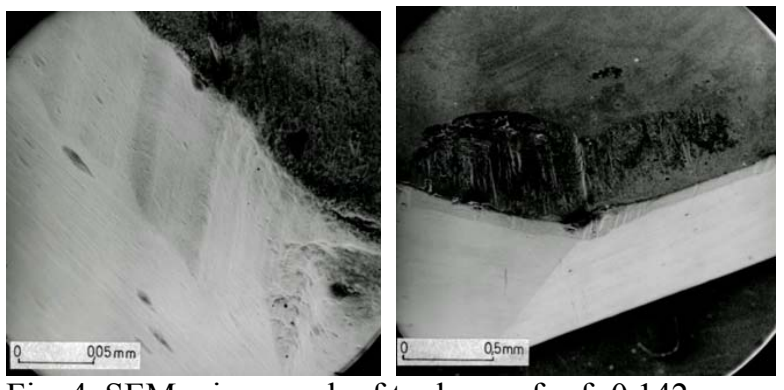

Fig. 4. SEM micrograph of tool wear for $\mathrm{f}=0.142$ $\mathrm{mm} /$ tooth

In Table 1 and 2 are presented experimental and modeled values of $\mathrm{VB}_{\mathrm{g}}$ - width of main flank wear land when processing with eight teeth and single tooth for different values of feed per tooth. These values also represent data for training the neural network.

\begin{tabular}{|l|l|l|l|l|}
\hline \multirow{2}{*}{$\begin{array}{l}\text { Processing } \\
\text { time [min] }\end{array}$} & \multicolumn{2}{|c|}{$\begin{array}{c}\text { 8 teeth wear } \\
\text { VBg }[\mathrm{mm}]\end{array}$} & \multicolumn{2}{c|}{$\begin{array}{c}\text { 1 tooth wear } \\
\text { VBg }\end{array}$} \\
\cline { 2 - 5 } & Exp. & Model & Exp. & Model \\
\hline 0 & 0 & 0 & 0 & 0 \\
\hline 1 & 0.06 & 0.0600 & 0.06 & 0.0600 \\
\hline 3 & 0.08 & 0.0800 & 0.09 & 0.0898 \\
\hline 5 & 0.12 & 0.1200 & 0.11 & 0.1106 \\
\hline 8 & 0.14 & 0.1400 & 0.14 & 0.1395 \\
\hline 10 & 0.16 & 0.1600 & 0.16 & 0.1603 \\
\hline 12 & 0.17 & 0.1700 & 0.18 & 0.1797 \\
\hline 15 & 0.19 & 0.1900 & 0.20 & 0.2002 \\
\hline 18 & 0.20 & 0.2000 & 0.22 & 0.2200 \\
\hline 20 & 0.23 & 0.2300 & 0.23 & 0.2295 \\
\hline 23 & 0.25 & 0.2500 & 0.24 & 0.2408 \\
\hline 25 & 0.26 & 0.2600 & 0.25 & 0.2494 \\
\hline 28 & 0.27 & 0.2700 & 0.26 & 0.2614 \\
\hline 30 & 0.28 & 0.2800 & 0.27 & 0.2693 \\
\hline 32 & 0.29 & 0.2900 & 0.28 & 0.2808 \\
\hline 34 & 0.30 & 0.3000 & 0.30 & 0.2997 \\
\hline 37 & 0.32 & 0.3200 & 0.34 & 0.3401 \\
\hline
\end{tabular}

Table 1. Width of flank wear for cutting speed $v=2.95$ $\mathrm{m} / \mathrm{s}$, depth of cut $\mathrm{a}=1.5 \mathrm{~mm}$ and feed per tooth $\mathrm{f}=0.223 \mathrm{~mm} /$ tooth

For case 8 teeth and 1 tooth face milling cuter parameters of tool wear: width of flank wear land $\mathrm{VBg}$, versus processing time and for cutting regime: cutting speed $\mathrm{v}=2.95 \mathrm{~m} / \mathrm{s}$ depth of cut $\mathrm{a}=1.5 \mathrm{~mm}$ and feed per tooth $\mathrm{f}=0.223 \mathrm{~mm} /$ tooth are on Fig 5 and for regime cutting speed $\mathrm{v}=2.95 \mathrm{~m} / \mathrm{s}$ depth of cut $\mathrm{a}=1.5 \mathrm{~mm}$ and of feed per tooth $\mathrm{f}=0.142 \mathrm{~mm} /$ tooth is on Fig 6 .

\begin{tabular}{|l|l|l|l|l|}
\hline \multirow{2}{*}{$\begin{array}{l}\text { Processing } \\
\text { time [min] }\end{array}$} & \multicolumn{2}{|c|}{$\begin{array}{c}\text { 8 teeth VBg wear } \\
\text { [mm] }\end{array}$} & \multicolumn{2}{c|}{$\begin{array}{c}1 \text { tooth VBg } \\
\text { wear [mm] }\end{array}$} \\
\cline { 2 - 5 } & Exp. & Model & Exp. & Model \\
\hline 0 & 0 & 0 & 0 & 0 \\
\hline 1 & 0.07 & 0.0698 & 0.07 & 0.0700 \\
\hline 3 & 0.08 & 0.0815 & 0.10 & 0.1000 \\
\hline 4 & 0.09 & 0.0898 & 0.11 & 0.1101 \\
\hline 6 & 0.10 & 0.1010 & 0.13 & 0.1298 \\
\hline 9 & 0.12 & 0.1196 & 0.14 & 0.1409 \\
\hline 11 & 0.13 & 0.1301 & 0.15 & 0.1483 \\
\hline 13 & 0.14 & 0.1400 & 0.16 & 0.1616 \\
\hline 15 & 0.16 & 0.1600 & 0.18 & 0.1793 \\
\hline 18 & 0.17 & 0.1700 & 0.20 & 0.2001 \\
\hline 20 & 0.18 & 0.1800 & 0.23 & 0.2300 \\
\hline 23 & 0.20 & 0.2000 & 0.25 & 0.2500 \\
\hline 26 & 0.22 & 0.2200 & 0.27 & 0.2700 \\
\hline 28 & 0.28 & 0.2800 & 0.28 & 0.2800 \\
\hline 29 & 0.33 & 0.3300 & 0.32 & 0.3200 \\
\hline 30 & 0.35 & 0.3500 & 0.36 & 0.3600 \\
\hline
\end{tabular}

Table 2. Width of flank wear for cutting speed $\mathrm{v}=2.95$ $\mathrm{m} / \mathrm{s}$ depth of cut $\mathrm{a}=1.5 \mathrm{~mm}$ and feed per tooth $\mathrm{f}=0.142 \mathrm{~mm} /$ tooth

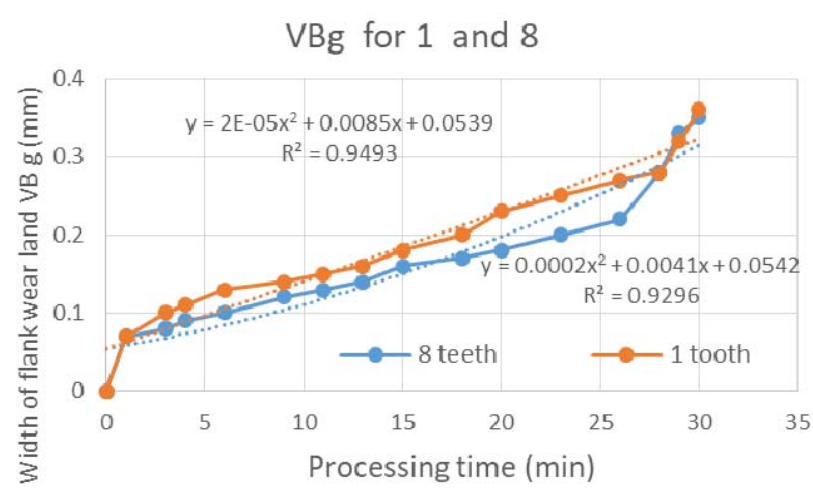

Fig. 5. Width of flank wear for cutting speed $v=2.95$ $\mathrm{m} / \mathrm{s}$, depth of cut $\mathrm{a}=1.5 \mathrm{~mm}$ and feed per tooth $\mathrm{f}=0.223 \mathrm{~mm} /$ tooth

VBs for 1 and 8

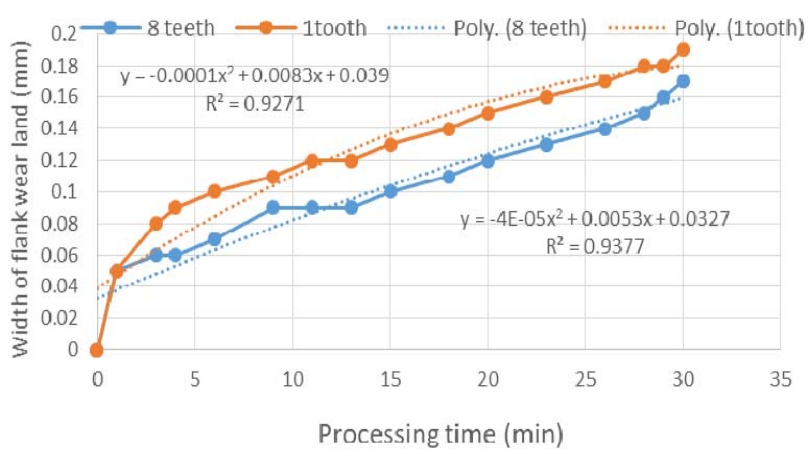

Fig. 6. Width of flank wear for cutting speed $v=2.95$ $\mathrm{m} / \mathrm{s}$ depth of cut $\mathrm{a}=1.5 \mathrm{~mm}$ and feed per tooth $\mathrm{f}=0.142 \mathrm{~mm} /$ tooth

The regression plot of the ANN for flank wear is 
shown in figure 7. The regression plots display the network outputs with respect to targets for training. From this plot, the value of the regression coefficient is found to be more than $99.9 \%$ which strongly justifies the acceptability in the prediction capability of the models. In case of the dry ANN model, the regression coefficient has a higher value; hence, it can be concluded that this model is accurate. From figure 7 can be seen that there is not significant difference between of wear parameters when machining with single tooth and with eight teeth. From graph of tool wear parameters can be concluded that tool life of single tooth and multi-tooth cutter is same if run-out of milling cutter tooth is very small, less than $\pm 0.002 \mathrm{~mm}$.
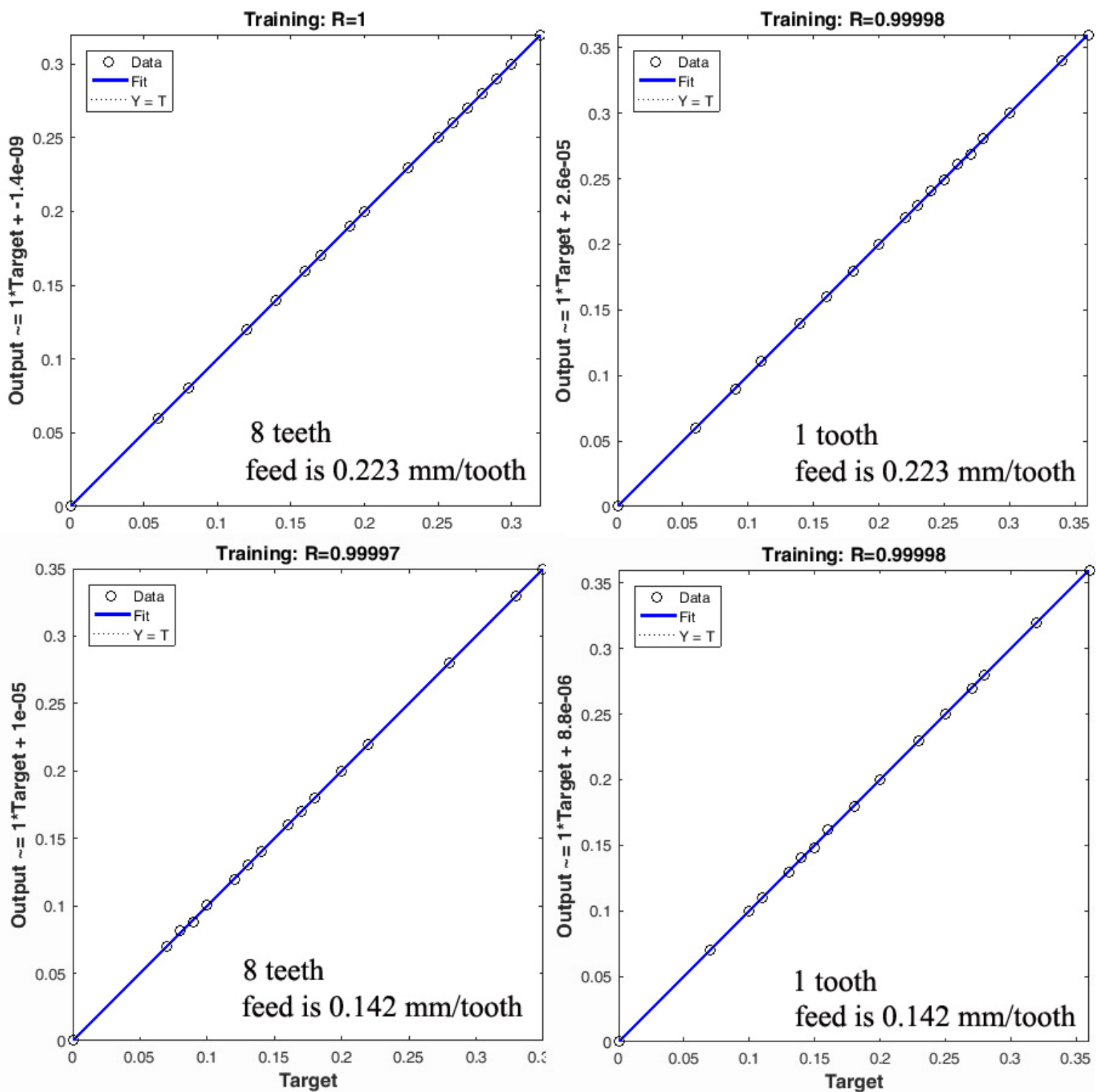

Fig. 7. Width of flank wear for cutting speed $\mathrm{v}=2.95 \mathrm{~m} / \mathrm{s}$ depth of cut $\mathrm{a}=1.5 \mathrm{~mm}$ and feed per tooth $\mathrm{f}=0.142$ $\mathrm{mm} /$ tooth

The learning function can be applied to individual weights and biases within the network. The LEARNGDM learning algorithms in feed-forward networks are used to adapt networks. Gradient descent method (GDM) was used to minimize the mean squared error between the network output and the actual error rate. It trains the network with gradient descent with the momentum back-propagation method. The back-propagation learning in feed-forward networks belongs to the real of supervised learning, in which the pairs of input and output values are fed into the network for many cycles, so that the network 'learns' the relationship between the input and the output.
For this study, feed-forward network was selected since this architecture interactively creates one neuron at a time. This is an optimization procedure based on the gradient descent rule which adjusts the weights of the network to reduce the system error is hierarchical. The network always consists of at least three layers of neurons: the input, output, and middle hidden layer neurons. The input layer has inputs, which is processing time. The output is the values of flank wear land. Three parameters were set to optimize the network performance: the number of hidden layers is 10 , the number of iterations is 100 and the number of neurons in the hidden layer is 10 . 
The results obtained by the feed-forward network, using TRAINLM algorithms for training and LEARNGDM algorithms for learning, show agreement with the experimental data. This shows that the selected parameters to optimize the network performance were a good choice.
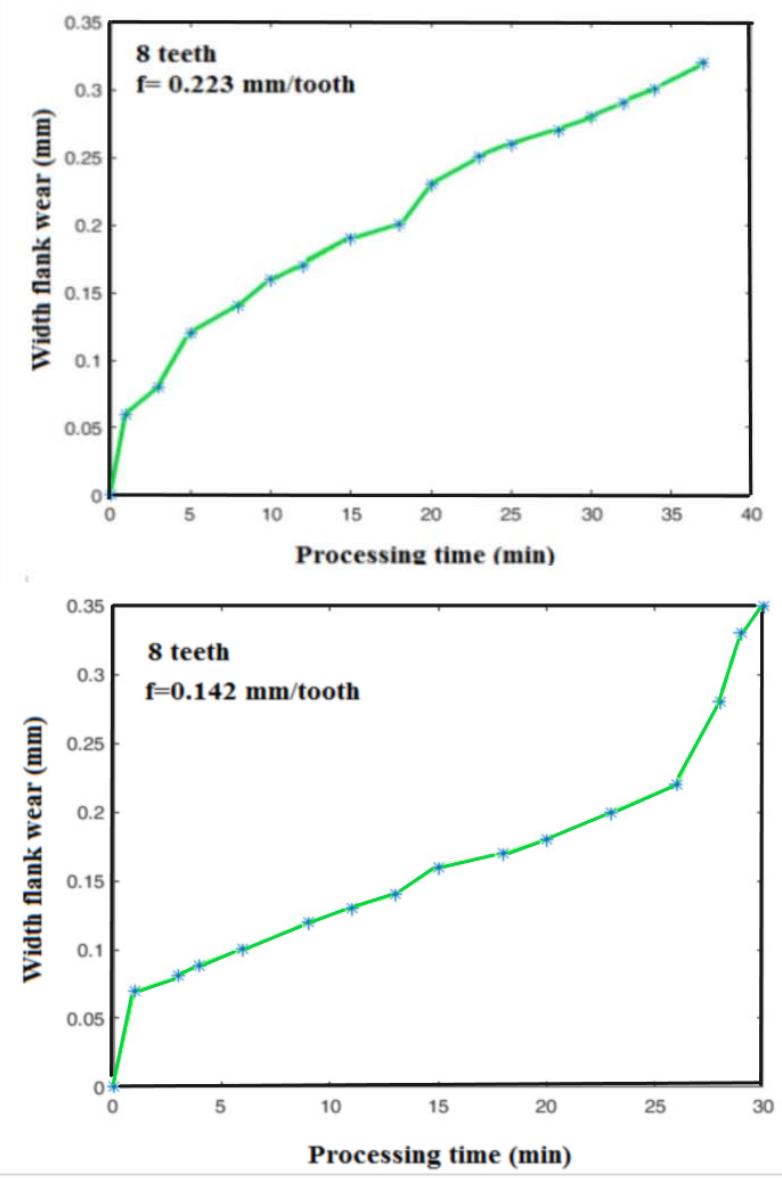

Fig. 8. Width of flank wear for cutting speed $\mathrm{v}=2.95 \mathrm{~m} / \mathrm{s}$ depth of cut $\mathrm{a}=1.5 \mathrm{~mm}$ and feed per tooth $\mathrm{f}=0.142$ $\mathrm{mm} /$ tooth

\section{CONCLUSION}

In this paper a neural network system for the prediction of the flank wear land has been introduced. The ANN model was developed based on the milling of correction steel C60. Observations indicate that the ANN modeling results of turning were in good agreement with the experimental findings, demonstrating that approximately $99 \%$ of the predictions were achieved. Experimental results showed that, The tool wear parameters of single tooth and multi-tooth cuter is similar if radial and axial throw of tooth is very small, less than $\pm 0.002 \mathrm{~mm}$. The comparison of ANN results with the experiment findings verified the high accuracy of the models. The neural network modeling technique could be an economical and successful method for the prediction of Tool wear parameters versus processing time as well as polinomial function.

\section{REFERENCES}

[1] Ber, A. and D. Feldman, The influence of radial

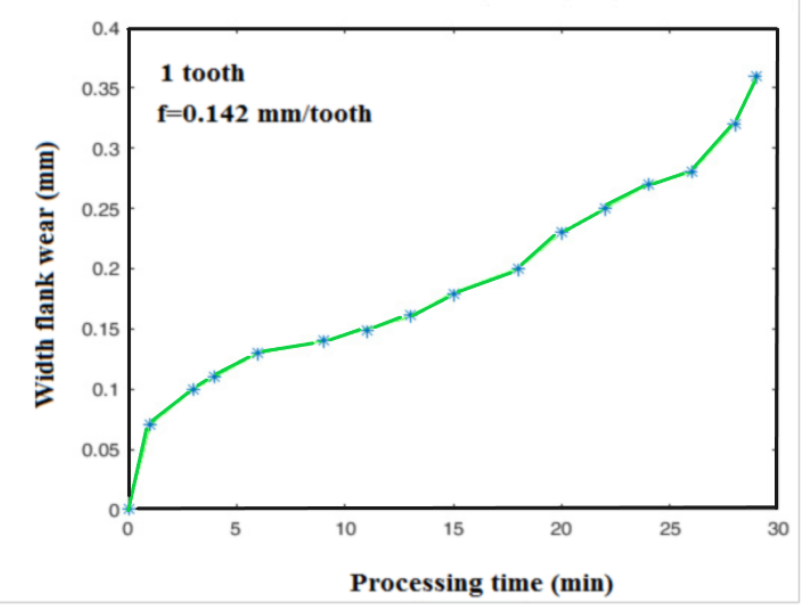

Research showed that NN model gives accurate, precise prediction on flank wear land. Figure 8 shows the response simulation graph of the flank wear land in terms of the processing time for various feed.

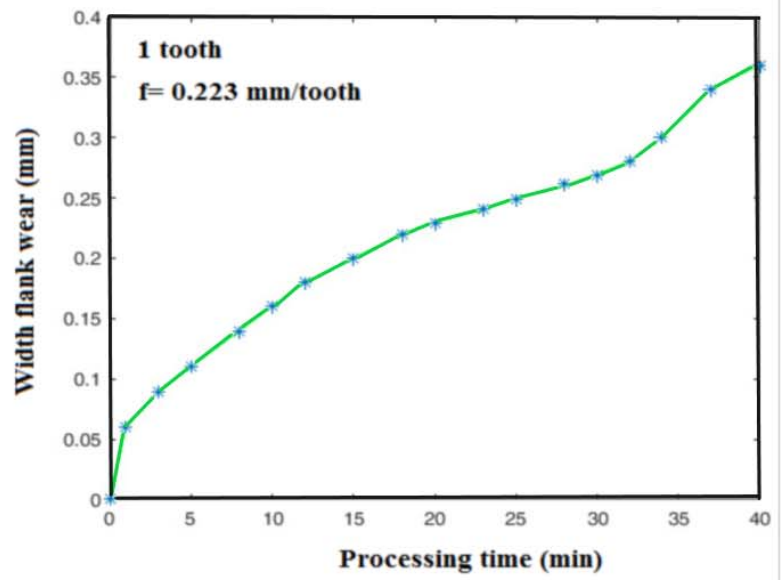


Engineering Manufacture, 2017: p. 0954405416683432.

[7] Bhattacharyya, P. and D. Sengupta, Estimation of tool wear based on adaptive sensor fusion of force and power in face milling. International Journal of Production Research, 2009. 47(3): p. 817-833.

[8] Srinivasa, P., T. Nagabhushana, and P. R. Rao, Flank wear estimation in face milling based on radial basis function neural networks. The International Journal of Advanced Manufacturing Technology, 2002. 20(4): p. 241-247.

[9] Pimenov, D. Y., A. Bustillo, and T. Mikolajczyk, Artificial intelligence for automatic prediction of required surface roughness by monitoring wear on face mill teeth. Journal of Intelligent Manufacturing, 2017: p. 1-17.

[10] Patowari, P. K., P. Saha, and P. Mishra, Artificial neural network model in surface modification by EDM using tungsten-copper powder metallurgy sintered electrodes. The International Journal of Advanced Manufacturing Technology, 2010. 51(58): p. 627-638.

[11] Tsai, K. M. and P. J. Wang, Predictions on surface finish in electrical discharge machining based upon neural network models. International Journal of Machine Tools and Manufacture, 2001. 41(10): p. 1385-1403.

[12] Pejic, V., Sekulic, M., Jokanovc, S., Kovac, P., Gostimirovic M., Modelling of cutting forces in ball-end milling process of hard (hardened) steel by using response surface methodology, Journal of production engineering, 2017, Vol. 20, (2), pp 17 -
20, http://doi.org/10.24867/JPE-2017-02-017

[13] Kovač, P., Rodić, D., Gostimirović, M., Savković, B., Ješić, D. Adaptive neuro-fuzzy modeling of thermal voltage parameters for tool life assessment in face milling, http://doi.org/10.24867/JPE-201701-016, Journal of Production Engineering (2017) Vol.20 (1) pp16-20

\section{ACKNOWLEDGMENT}

This paper is the result of the research within the project TR 35015 financed by the Ministry of Science and Technological Development of the Republic of Serbia and Billateral project Serbia-Slovakia

Authors: ${ }^{1}$ Professor Pavel Kovac PhD, ${ }^{1}$ Assist. Professor Borislav Savkovic PhD, ${ }^{1}$ MSc Dragan Rodic, ${ }^{1}$ Professor Marin Gostimirovic, ${ }^{2}$ Professor Ildiko Mankova PhD.

${ }^{1}$ University of Novi Sad, Faculty of Technical Sciences, Institute for Production Engineering, Trg Dositeja Obradovica 6, 21000 Novi Sad, Serbia, Phone.: +381 21 450-366, Fax: +381 21 454-495.

${ }^{2}$ Technical University of Košice, Faculty of Mechanical Engineering, Deptartment of Manufacturing Technology and Materials, Mäsiarska 74, $040 \quad 01$ Košice.

E-mail: pkovac@uns.ac.rs

savkovic@uns.ac.rs

rodicdr@uns.ac.rs

maring@uns.ac.rs

ildiko.mankova@tuke.sk 